\title{
A ORDEM SAGRADA DA REPÚBLICA COLONIAL ${ }^{\mathrm{i}}$
}

\author{
Rodrigo Almeida Bastos ${ }^{1}$
}

“... tanto mais que logo el-rei reconstitui a ordem e a solenidade que convém às coisas sagradas..."

José Saramago, Memorial do Convento

Em 30 de maio de 1730, foi registrada uma "promessa" feita pelos oficiais da Câmara de Vila Rica a respeito da "fatura" da "nova" Igreja Matriz de Nossa Senhora do Pilar. A Mesa da Irmandade do Santíssimo Sacramento suplicava auxílio para erguer com mais "segurança" e "capacidade" uma "nova igreja matriz", e o faziam porque a igreja que existia, relatavam, estava "pequena e arruinada, com termos de cair". Às irmandades do Santíssimo Sacramento geralmente tocavam as igrejas matrizes, representantes que eram do mais importante sacramento da Igreja católica, a Santa Eucaristia, pelo qual os fiéis participam do corpo e do sangue de Jesus Cristo, como reafirmação de sua integração espiritual ao "corpo místico" do próprio Cristo e da Santa Igreja. Requeriam os irmãos do Santíssimo, com o consentimento uniforme de todos os "freguezes" e das "autoridades" do "prelado" e do "pároco", que Vila Rica se "aumentava" muito, como "cabeça" das outras povoações, e que portanto era preciso erigir outra igreja "mais durável" e "grande" para se acomodar tudo com maior "capacidade" e "segurança". E argumentavam que "tudo" se deveria fazer e "aperfeiçoar" em proveito de interesses comuns - "régio, público e particular" - para os quais concorriam especialmente os "templos", tratados no documento como o "mais firme e fixo fundamento, como colunas que são das Res publicas pias e cristãs, e almas delas,

Vila Rica era "cabeça” das povoações mineiras, uma vila de faustas riquezas, mas sem o "braço" superior da coroa, argumentaram os irmãos, seria "impossível aperfeiçoar a

\footnotetext{
1 Engenheiro civil e arquiteto (e-mail:digobastos@gmail.com); mestre em arquitetura pela UFMG, doutorando em História e Fundamentos da Arquitetura e do Urbanismo pela FAU-USP (pesquisa realizada com o apoio da FAPESP - Fundação de Amparo à Pesquisa do Estado de São Paulo).
} 
obra da dita Igreja para com a devida decência se celebrarem nela os ofícios Divinos”. E não se tratava de uma igreja qualquer. Era a matriz de uma povoação que, no termo dos redatores, "encabeçava" as demais da capitania. Ao registar, no arremate do documento, a efetiva promessa do senado de "doze mil cruzados" como "esmola avantajada" para "finalização" e "subsistência" da obra, voltou-se a louvar a dita igreja como "sempre" "preferida por Matriz", "por cujos respeitos se faz[ia] digna" de "representar" a vila. A obra era portanto mais do que "necessária", então declarada "piíssima",iii, "para nela melhor se poderem celebrar - atente-se - as funções da República, com a devida solenidade, aparato e grandeza"iv

É de conhecimento geral a magnificência final da Igreja de Nossa Senhora do Pilar de Ouro Preto, da elegância ornamental de seu interior (a fachada sofreu alterações no século XIX). A posse dos governadores da capitania geralmente se dava na própria Igreja Matriz, teatro sacro privilegiado dos valores teológico-retóricos encenados continuamente pela arquitetura religiosa do século XVIII, importantes para toda a república. O documento evidencia com clareza de argumentos, matéria e elocução, quais seriam os "fundamentos", as "colunas" da república católica portuguesa. E a alegoria foi bastante apropriada: como edifícios religiosos, os templos foram analogamente proporcionados às "colunas" do edifício político do reino, fundamento de índole espiritual e moral de seu corpo místico.

Por mais que o documento contenha referências enfáticas quanto à conveniência e à dignidade da obra, e também aos preceitos a serem seguidos no seu "aperfeiçoamento", dentre os quais :"decência", "capacidade", "durabilidade", “aparato", "grandeza”, o que poderia indicar que a fábrica artístico-construtiva em Minas Gerais satisfizesse eficazmente a todos os interesses, necessidades e efeitos, em dois de abril de 1739 foi registrado um outro documento bastante curioso e pertinente. Nele, D. João V mandou "publicar", em todas as "partes em que for preciso", que os fiéis não se "intrometessem" a "reedificar" ou "ampliar" as "igrejas paroquiais" sem antes informar o Provedor da Fazenda Real, que mandaria "fazer planta proporcionada à necessidade"v . Com a regulação pretendia-se evitar, como declarado no documento, além de "superfluidades", a "desordem" com que "regularmente" se empreendiam as obras das igrejas paroquiais na capitania de Minas Gerais. Não está claro que "desordenadas” tenham sido feitas as obras da Igreja de Nossa Senhora do Pilar. O documento não exemplifica, apenas 
generaliza as obras paroquiais "regulares" da capitania, mas deixa uma indagação importante no ar, praticamente inevitável, sobretudo se conhecemos minimamente a historiografia da arquitetura colonial luso-brasileira erigida no século XX. A questão é: o que se entendia por "ordem" no século XVIII? Qual a sua importância para as obras de arte e arquitetura? Qual a sua relação com os preceitos artísticos vigentes no período, citados no primeiro documento?

Pretende-se, pois, examinar neste texto o que se entendia por "ordem" no período crucial de formação das povoações de Minas Gerais, ou seja, início e meados do século XVIII. Este texto faz parte de uma pesquisa mais ampla, iniciada no mestrado (EAUFMG) e empenhada atualmente no doutorado (FAU-USP), ambos sobre a arquitetura e o urbanismo de Minas Gerais no século XVIII. O texto é ainda uma primeira aproximação, uma primeira reflexão acerca dessa específica noção de "ordem", muito importante para compreendermos não apenas as relações que existiam entre os edifícios e a cidade colonial, como também as relações entre os edifícios, a cidade e seu complexo contexto cultural. Para melhor compreendê-los, vale a pena pensar que no século XVIII não existiam duas disciplinas assim como as tratamos hoje - arquitetura e urbanismo - e que os princípios que regiam e orientavam suas formações, dentre eles a noção de "ordem", eram os mesmos, correspondentes a outros regimes de compreensão, produção e recepção das artes que também não são exatamente os nossos. Procurarei desenvolver aqui alguns pressupostos da noção de "ordem", assim como fundamentados na política e na poética teológico-retórica vigente nos séculos XVII e XVIII.

A procura por um sentido de ordem mais coerente com o período em questão é bastante necessária, tanto para rever antigas verdades como para alimentar novas pesquisas que procurem compreender o passado através também, e sobretudo, da reconstituição das categorias e conceitos próprios e contemporâneos desse mesmo passado. Durante boa parte do século XX, e principalmente em trabalhos reconhecidos paradigmáticos por décadas, como os de Sérgio Buarque de Holanda e Robert Smith ${ }^{\text {vi }}$, a noção de "ordem" esteve contaminada por acepções anacrônicas ou estranhas ao regime teológico-retórico que sustentava a produção artística na América portuguesa durante o século XVIII. Nesses trabalhos, a ordem foi geralmente compreendida como homóloga ou mesmo sinônima de uniformidade e retidão geométricas. Isto fez com que, durante muito tempo - enquanto os estudiosos equivocadamente entenderam a adaptação das estruturas 
construídas ao sítio como um sintoma negativo de "espontaneidade" ou "desleixo" -, se considerasse que os portugueses ou "ignoravam" ou "desconheciam" a "ordem". Pretende-se mostrar, contudo, que a noção de ordem foi fundamental ao universo lusobrasileiro, e que essa noção, coerente com o período, constituía antes um princípio, e não apenas um atributo formal ortodoxo, uniformidade ou retidão geométricas; a ordem constituía antes de tudo um princípio de organização, uma causa apta a proporcionar proveitos, aparências e efeitos convenientes aos interesses da política colonial portuguesa, e parece ter sido fundamental para a formação das povoações coloniais de Minas Gerais, reclamada nos documentos setecentistas, como vimos, que tratam justamente das fábricas artístico-construtivas.

A noção de "república" considerada aqui não é, obviamente, a que corresponde ao reconhecimento político moderno das repúblicas federativas e das liberdades pósiluministas individuais e institucionais, mas sim a que corresponde ao Antigo regime português (1620-1807). A res publica absolutista portuguesa concernia ao "bemcomum", mas não como espaço da livre-manifestação individual e coletiva; concernia ao bem-comum como espaço sobretudo de representação - representação de uma ordem considerada "sagrada", fundamental à coroa portuguesa, capaz de sustentar teoricamente e justificar a ética e a moral, a hierarquia, a coesão e a concórdia entre as partes do reino, o projeto colonizador e a escravidão, os privilégios e as mercês, as artes e a constituição das cidades.

A política colonial da coroa portuguesa estava baseada fundamentalmente em pressupostos teológicos, sacralizados no final do século XVI e durante os séculos XVII e XVIII, período em que se desenrola a reforma católica. Dessa "política teológica"vii manavam os postulados e regulações relativos à fundação, conservação e aumento de toda a república católica portuguesa, disseminados a todas as instituições e "partes" do "corpo místico" do reino, metropolitanas e ultramarinas. Princípio e fundamento mimético dessa política teológica, a "ordem” deveria orientar também, além da organização do próprio estado e sua administração, a implantação de povoações, a fábrica da arquitetura e sua ornamentação, autorizando continuamente valores de integração corporativa, decoro e hierarquia coerentes não apenas com a política, mas também com o regime retórico-poético que determinava, internamente, procedimentos e princípios para a produção das artes no século XVIII. Recuperando uma noção coeva de 
ordem, procura-se demonstrar também como a cultura do século XVIII luso-brasileiro sustentou a compreensão da cidade como um artefato sagrado, "parte" (composta de "partes") integrante de um "corpo" político de fundamentação mística, em que se compreendia Deus como causa imanente e primeira, mas também como fim de todas as ações e produções humanas amparadas pelo catolicismo. Sob o ponto de vista da lei dos homens, os lugares considerados sagrados eram aqueles estritamente reconhecidos pelos seus limites edificados, templos, adros, sacristias, seminários etc. Sob a compreensão da lei natural, divina ${ }^{\text {viii }}$, todavia, pode-se dizer que era sagrada a cidade, "parte" material e representativa de um "corpo místico" - de caráter sagrado - do reino ou da República católica absolutista. Os sinais remanescentes dessa compreensão estão ainda presentes nessas cidades: igrejas e capelas, passos, chafarizes e pontes devidamente ornados, geralmente encimados por cruzes e alegorias do estado eminentemente católico português, como que a lembrar continuamente o pressuposto que justificava teologicamente a própria existência da cidade, consolidação material e simbólica da conquista e da expansão do reino de Deus sobre a terra (profetizada em tantas passagens das sagradas escrituras). E será justamente esse pressuposto, por assim dizer, missionário, uma das principais justificativas para as diversas empresas dos reis católicos no novo mundo, monarcas que se advogavam representantes de Deus e coadjutores de seus desígnios.

A república católica portuguesa estava fundada num pacto de sujeição (pactum subjectionis) ${ }^{\text {ix }}$ através do qual os súditos e vassalos, não apenas os colonos, se alienavam do poder em nome da figura pública do rei - um iluminado pela graça divina, segundo as doutrinas neo-escolásticas vigentes em Portugal no século XVIII -, "cabeça" do corpo místico do reino em analogia proporcional ao corpo místico da Igreja Católica Romana, tendo Jesus Cristo como cabeça (caput). Agregando interesses políticos e econômicos, mas também católicos e proselitistas, todos expansionistas, a administração e a regulação da coroa se sustentavam principalmente através de valores e princípios teológicos - uma espécie de extensão da lei natural divina, presente desde o princípio e indiscutivelmente superior à lei redigida pelos homens, que aquela deveria imitar como participação na ordem com a qual Deus rege o universo. São bastante conhecidas as recomendações tridentinas para a confecção de imagens religiosas, sobretudo o resguardo do decoro e da decência devida às coisas sagradas, as representações de Jesus Cristo, da virgem e demais personagens e cenas bíblicas. As sagradas escrituras 
constituíam fonte imprescindível, proporcionando modelos discursivos ou poéticos para as representações artísticas que o artista deveria seguir na invenção, na disposição e na elocução. Mas não apenas isso. Algumas passagens das sagradas escrituras constituíam verdadeiros modelos jurídicos, baseados na autoridade incontestável da "palavra de Deus" (Verbum Dei), também para a formulação das leis e para a administração dos príncipes católicos.

O termo "ordem" advém do latim ordo, e siginifca "ordem, arranjamento, disposição", como se encontra no dicionário Latino-português de Santos Saraiva (1927). Segundo o uso dos autores latinos, os significados do termo se expandem a partir desta noção comum de "disposição", "arranjo" das coisas cada qual em seu lugar adequado e conveniente, conforme natureza, propriedades e coerência. No Vocabulário Português e Latino de D. Raphael Bluteau, dedicado ao próprio rei D. João V em 1712, o primeiro registro para o termo é bem explícito: "ORDEM: disposição, assento, ou colocação das cousas no lugar que lhe[s] convém"xi

Enquanto a Retórica e Poética sustentaram as Artes, a "ordem" foi tradicionalmente entendida como "disposição" adequada e "conveniente" dos membros ou das partes que compõem uma obra. Vinculadas convenientemente, essas partes deveriam constituir um "corpo" como que "vivo", metáfora modelar recorrente, desde a antiguidade grecolatina, para se tratar das instituições e produções humanas, dos discursos às artes, enfaticamente a arquitetura. Foi do poeta Píndaro a célebre comparação da arquitetura a um discurso poético, em que as primeiras palavras do poema seriam análogas à fachada de um edifício, introdutórias do tema, do caráter, e demais atributos da arte. Compreendendo o discurso ordenado por uma espécie de lei (nomos), Górgias comparou a composição em versos poéticos não diretamente ao próprio corpo, mas a uma espécie de "vestimenta" moldada em métricaxii. É de Protágoras a famosa sentença: "O homem é a medida de todas as coisas" "xiii. No Fedro, Platão defendeu através de Sócrates a idéia de que "todo o discurso deve ser formado como um ser vivo e ter seu organismo próprio; não deve faltar-lhe a cabeça nem os pés, e tanto os órgãos centrais como os externos devem estar dispostos de maneira que se ajustem uns aos outros, e também ao conjunto"xiv . Para Aristóteles, a beleza de qualquer coisa "composta de partes" depende de sua "extensão" e de sua "ordem"xv . Na introdução à Arte Poética (Epistola ad Pisones), Horácio introduziu a unidade do poema como disposição 
adequada e coerente das partes de um corpo, desfeita a qual não se poderia conter o riso ${ }^{\mathrm{xvi}}$.

O entendimento da constituição dos "corpos" nas repúblicas católicas também se sustentou com o uso da tradicional tópica retórico-poética do "corpo" bem disposto, ordenado, interpretado porém sob chave cristã. Assim como o Amor (Philía) e a Harmonia $^{\text {xvii }}$ - empregados ora como personificações de divindades ora como atributos técnico-musicais - eram responsáveis pela união e conveniência das partes ou membros nos corpos antigos, o vínculo que perpassava e justificava a unidade constitutiva dos corpos cristãos também assimilou os atributos de harmonia, ordem, conveniência e proporção, revestido porém de uma índole sagrada adequada. O vínculo cristão então apto a unificar e ordenar era o próprio "Espírito", representação do amor de Deus (prometido por Jesus Cristo aos apóstolos ${ }^{\text {xviii }}$ ) que haveria de conveniar os homens e iluminá-los cada qual para o desempenho máximo de suas naturezas, carismas e virtudes, e para a adequada congregação em sociedade - tudo em satisfação do projeto divino ao qual os homens são orientados, apesar do pecado original, pela consciência da reta razão e pela luz da graça inata ${ }^{\text {xix }}$.

A utilização cristã da tópica poético-retórica ${ }^{\mathrm{xx}}$ do "corpo" e que legitima a instauração e o reconhecimento da ordem cristã foi consagrada por São Paulo na primeira epístola aos Coríntios, quando, muito oportunamente entre gregos ${ }^{\mathrm{xxi}}$, enunciou o "corpo místico" de Cristo e de sua Igreja, todos os membros vinculados e "impregnados" pelo amor do mesmo "Espírito".

Porque, como o corpo é um todo tendo muitos membros, e todos os membros do corpo, embora muitos, formam um só corpo, assim também é Cristo. Em um só espírito fomos batizados todos nós, para formar um só corpo, judeus ou gregos, escravos ou livres, e todos fomos impregnados do mesmo Espírito. Assim o corpo não consiste em um só membro, mas em muitos. [...] Mas Deus dispôs no corpo cada um dos membros como lhe aprouve. Se todos fossem um só membro, onde estaria o corpo? Há, pois, muitos membros, mas um só corpo. O olho não pode dizer à mão: "Eu não preciso de ti", nem a cabeça aos pés: "Não necessito de vós". Antes, pelo contrário, os membros do corpo que parecem os mais fracos, são os mais necessários. E os membros do corpo que temos por menos honrosos, a esses cobrimos com mais decoro. Os que em nós são menos decentes, recatamo-los com maior empenho, ao passo que os membros decentes não reclama tal cuidado. Deus dispôs o corpo de tal modo que deu maior honra aos membros que não a têm, para que não haja dissensões no corpo e que os membros tenham o mesmo cuidado uns para com os outros. Se um membro sofre, todos os membros padecem com ele; e se um membro é tratado com carinho, todos os outros se congratulam por ele. Ora, vós sois o corpo de Cristo e cada um, de sua parte, é um dos seus membros. Na Igreja, Deus constituiu primeiro os apóstolos, em segundo lugar os profetas, em terceiro lugar os doutores, depois os que têm o dom dos milagres, o dom de curar, de socorrer, de governar, de falar diversas línguas. [...]"xxii. 
O corpo se forma por união ou associação de membros diversos, e a união coerente desses membros é "ordem". Assim como o corpo humano - modelo exemplar, pagão e cristão (à semelhança de Deus), de “disposição" divina - é composto de várias partes diversas umas das outras, cada qual desempenhando uma função específica para o bem comum do organismo, o corpo da igreja, e mais tarde das sociedades e repúblicas com ela e por ela fundamentadas, é composto de partes ou membros também singulares, cada qual em sua posição e cumprindo sua função também específica, convenientes uns aos outros e sobretudo ao todo. O fim dessa integração ordenada e conveniente (decorosa) das partes é o proveito comum do todo, a integridade e a conservação do corpo. "A cada um é dada a manifestação do Espírito para proveito comum”, justificara Paulo versículos antes de enunciar o "corpo místico" de Cristo. Cada parte ou membro contribui e participa segundo sua natureza, decoro, posição e hierarquia, e exerce um papel fundamental - necessário a todos os outros membros e também ao bem comum do todo - ao conjunto que se deve contemplar perfeito, proporcionado e decente, ordenado enfim.

Assim como Paulo contemplara o corpo de Cristo e da Igreja unidos e impregnados pela ação do espírito, as repúblicas católicas verão seus corpos político-sociais impregnados por um fundamento também espiritual. Segundo Francisco Suarez - um dos eminentes teólogos da chamada "segunda escolástica", a teologia que fundamentou as repúblicas católicas contra-reformistas - é fundamentalmente uma "união" de tipo "espiritual" que define estas repúblicas; uma união espiritual que se apresenta socialmente como "união moral" pois estabelecida pelos homens a partir do bom uso da reta razão e regulada pela moral católica. Para Suarez, cujas principais obras foram apresentadas e estudadas durante o século XVII nos Cursos de Cânones da Universidade de Coimbraxxiii, "a união moral é fundamentalmente uma ordem”. Suarez segue de perto São Tomás de Aquino, para quem a "sociedade é uma unidade de ordem"xxiv . Santo Agostinho também definira a ordem socialmente: uma pluralidade de elementos que se unem moralmente quando devidamente dispostos na comunidade ("parium dispariumque sua cuisque tribuens loca, dispositio") ${ }^{\mathrm{xxv}}$. O homem é um ser social, os teólogos católicos concordam com Aristóteles na definição da natureza humana, e a formação de uma república ordenada seria um dos meios mais eficazes pelos quais o homem poderia ser levado à plenitude 
de suas virtudes, à plenitude de sua natureza única e privilegiada - graça divina. Especialmente as cidades, enquanto artefatos ordenados integrados à ordem sagrada da república, são vistas muito convenientes ao gênero humano. $\mathrm{Na}$ "cidade", produto síntese da cultura, o homem pode encontrar tudo o que precisa para viver e desenvolverse no conhecimento da ordem, e a participar dela plenamente, em corpo e espírito. A cidade proporciona, ou deve proporcionar, "comodidade" ao corpo do homem, assim como encarna e encena as leis das coisas espirituais, as quais o homem deve seguir e se integrar $^{\text {xxvi }}$. A integração do homem ao corpo místico do estado se dá nesta íntima participação social, corpórea e espiritual. A ajuda da sociedade é efetivamente material, física, mas ao promover o desenvolvimento da vida propriamente humana, esta ajuda se dirige e se reveste, cada vez mais, de uma "índole espiritual, e dirigida à conquista do reino do espírito"xxvii. Seguindo os ditames da Natureza, a República colabora então para realizar a "ordem sobrenatural que gratuita e generosamente Deus estabeleceu entre os homens"xxviii. Essa ordo naturalis, que Deus introduz na natureza através de sua lei eterna, o homem deve "reproduzir a seu modo no mundo da cultura, dentro do qual se encontra a própria república" e suas manifestações e representações físicas, a cidade, a arte etc. ${ }^{\text {xix }}$ "Criar uma cultura - neste contexto católico contra-reformista - é colaborar com Deus no acabamento de sua própria obra, por isso toda verdadeira cultura está sempre animada por um sopro divino" ${ }^{x x x}$. O homem é apenas um instrumento divino na criação da cultura, iluminado pela graça divina que aperfeiçoa a natureza ${ }^{\text {xxi }}$.

A conservação do corpo político foi uma das prioridades das repúblicas católicas. Dentre as três principais estratégias concernentes à administração dos estados: "fundação", "aumento" e "conservação", João Botero, um dos principais teóricos da razão de estado católica ${ }^{\text {xxii }}$, considerava a conservação a mais importante delas. Nos documentos setecentistas de Minas Gerais a referência à "conservação" da república católica é constante. Embora fosse preciso consolidar novas "conquistas", efetivar "novos descobrimentos mineradores", "aumentar" as cidades, em tamanho e dignidade, impunha-se sobretudo conservá-las, mantê-las, cômodas e decentes.

Se para Francisco Suarez a "união" era "ordem”, para João Botero a "desunião" era sinal de "desordem",xxxiii. Manter a concórdia entre os membros e partes do reino se impunha como necessidade imprescindível, e para isso a noção de Justiça foi um fundamento. A "discórdia" entre os membros era compreendida como uma doença, que 
comprometia a "sanidade" do "corpo do estado"xxxiv . Botero argumentava com o exemplo de Jesus Cristo que, ao instituir sua "Santa Igreja", uniu-a com o amor da caridade, através da qual, alta virtude, nem seria necessário que se impusesse entre os homens a justiça. Todavia, "como os homens são normalmente imperfeitos e a Caridade vai continuamente se arrefecendo, é preciso, para pôr ordem nas Cidades e manter em paz e tranqüilidade a comunidade dos homens, que a Justiça nelas se implante e seja exercida"xxxv.

Numa sociedade essencialmente hierarquizada, a justiça foi entendida não como igualdade absoluta para todos, mas o que proporcionasse a cada um aquilo que devidamente lhe coubesse segundo sua posição e méritos dentro do corpo social. Em teoria, a Justiça era uma espécie de "harmonia", uma "proporção", preceitos consagrados também no campo da arte. A definição é grega, aparece na ética $\operatorname{aristotélica~}^{\mathrm{xxxvi}}$, cristianizada por São Tomas de Aquino segundo o qual a "justiça" é o que se "ajusta" ou "cai tão bem" de modo que não resultam sobras ${ }^{\text {xxxvii }}$. Na ética da razão de estado católica, a ordem se constrói essencialmente através da justiça. E fazer justiça é conformar-se com a "lei eterna", aspirar realizar a "ordem universal”. O estado deve, pois, ter um ideal de justiça "conforme o qual estabeleça suas normas". E a ordem a ser traçada daí há que ser participação da razão ou da "ordem" que o ser supremo legislador usa para reger o universo ${ }^{\text {xxxviii }}$. Importantes não são, positivamente, as leis ou o direito, senão os fins que se devem perseguir através deles e de outras virtudes: a paz e a concórdia; a suficiência de bens que sustentem a conservação e a comodidade da vida corporal; a honradez dos costumes que é necessária à paz externa e a felicidade da república $^{\mathrm{xxxix}}$.

Como destacou Rocafful, no comentário sobre o estado e a república na teologia política de Francisco Suarez, a "Ordem" se manifestava em "uma série de normas, as vigentes em cada sociedade, escritas ou consuetudinárias, com as quais se determina o seu fim e os meios para consegui-lo" "xl. Estas "normas" deveriam produzir essencialmente o bem comum, garantindo a concórdia, a harmonia e a paz da república, a integridade de seus membros e partes, a comodidade do corpo e o aprimoramento virtuoso, moral e espiritual do homem. Sendo a cidade o lugar por excelência da cultura da república, as artes teriam que ser, também, "lugares" por excelência da manifestação da ordem. A ordem se manifestava, pois, nas "normas" que deveriam perseguir o bem comum, mas 
também na materialidade física da república, encarnando, por assim dizer, os valores que sustentavam a coesão espiritual e moral dos membros do corpo político, as hierarquias e proporções, evidenciando sempre o fundamento teológico das ações e produções humanas que se justificavam, via de regra, na contribuição humana aos desígnios de Deus. As artes eram um suporte privilegiado para a compreensão dessa ordem, a funcionar como teatro permanente de valores sagrados que sustentavam a hierarquia social. Como o fundamento das artes era sagrado, e também a maioria dos temas das representações artísticas, que os artistas deveriam imitar das escrituras sagradas e da tradição, no século XVI os jesuítas alcunham a expressão Theatrum Sacrum, para se referir à estratégia de manifestação das artes em seio católico ${ }^{x l i}$. Fundamentando-se teológica e retoricamente, as artes seis e setecentistas - letras, imaginária, arquitetura, música etc. - funcionavam todas como um teatro sacro, encenação continua dos valores, pressupostos e princípios sagrados da igreja católica.

Integrando-se hierarquicamente à ordem de todo corpo político, um edifício de arquitetura deveria apresentar uma ordem ou disposição específica adequada ao seu contexto e circunstâncias próprias. A ordem da arte e da cidade faziam parte da ordem político-teológico; serviam a ela, alimentando-se dos mesmos princípios, conveniência, decoro, hierarquia, dignidade, concórdia, justiça, harmonia, proporção etc. Por exemplo: um edifício como o Templo da Irmandade da Ordem terceira de São Francisco de Assis de Vila Rica. Seu frontispício possui elementos característicos da Ordem, notadamente a representação do transpasse das chagas de Cristo ao santo, representação coerente com a lógica, com a história e com o caráter da Irmandade, e que proporciona um discurso teológico-retórico apropriado e singular, diante dos discursos também específicos das demais ordens e irmandades. Todavia, esses discursos e essas disposições específicas dos edifícios se integravam ao discurso maior do corpo místico, mantendo sua individualidade mas contribuindo, enquanto parte, para o bem comum católico do todo. Sob o engenhoso óculo cegado da capela de São Francisco, onde Aleijadinho figurou o transpasse das chagas, a portada é disposta e ornada com elementos que filiam o corpo da Ordem ao "corpo místico"xlii do reino português. Estão lado a lado as cinco chagas de Cristo (e do santo) e os cinco escudetes do brasão de Portugal (uma alegoria teológicoretórica de proporção), encimados, no mais alto da composição além do busto da virgem, por uma coroa dominada por uma cruz (ícone sobreposto das majestades divina e portuguesa ali engrandecidas pelo ornato que encena, dignificando por decoro e 
formosura, o seu discurso). Cada parte efetuava, portanto, o seu discurso próprio e adequado, unido aos outros e ao discurso integral da cidade e da república, como conjunto de partes que se integravam hierárquica e convenientemente. Os fundamentos e preceitos desse discurso específico, enquanto corpo que se integrava a outro corpo maior e comum, são basicamente os mesmos, pois deveriam reproduzir continuamente as normas e valores gerais da ordem sagrada: Deus (causa primeira e fim de todas as coisas), a hierarquia (da igreja, do reino e das instituições), a conveniência (utilidade, harmonia e concórdia das partes), dignidade e decência.

Realizar analogias entre o corpo místico e o corpo artístico seria um risco, não fosse considerado o regime retórico-teológico vigente nas repúblicas católicas. Assim como todos os membros do corpo místico estavam conveniados, concordados e ordenados pela vinculação amorosa do espírito, os membros ou partes das obras careciam sempre de um sentido de conveniência. João Adolfo Hansen alertou para a importância da metáfora aristotélica-estóica da "amizade" para fundamentar a noção de concórdia nas monarquias católicas ${ }^{\text {xliii }}$. Nos tratados artísticos e também nos documentos de época, a "conveniência" aparece com dois sentidos básicos: 1) a conveniência é uma propriedade que as partes apresentam por estarem bem umas com as outras e com o todo, e, 2) a conveniência é uma utilidade, um proveito usufruído pelas partes e pelo todo. Pode-se aferir que a conveniência aparece primeiro como um princípio de composição e aglutinação das partes, convir com, vir bem com, e, segundo, como uma finalidade desta mesma organização; ou seja: a conveniência como bom arranjo das partes proporciona uma conveniência como utilidade ou proveito. Assim como no modelo do corpo humano (para os antigos gregos e para São Paulo), as partes estão bem arranjadas umas com as outras, proporcionando uma aparência harmônica e coesão estrutural ao organismo, esse bom arranjo permite concluir que todas as suas partes e o corpo como um todo são úteis entre si e para o todo do corpo. Estão todas as partes em concórdia, ordenadas entre si e com o todo em prol de proveitos comuns, que cada parte proporciona segundo sua própria natureza e ao mesmo tempo usufrui, enquanto parte indivisível do corpo ${ }^{\text {xliv }}$.

Politicamente, essa concórdia ordenada de partes e conveniências deve ser vista como associação inquestionável de homens, estamentos e instituições, que deveriam contribuir, cada qual ao seu modo, cabedal, natureza e posição, para o bem comum do 
estado. Artisticamente, essa concórdia de conveniências deve ser vista como arranjo decoroso e ordem, colocação conveniente de cada parte do corpo artístico em seu lugar e posição apropriados, em sua proporção adequada, coerente estilisticamente com o gênero, com o assunto e com a finalidade da obra - a recepção adequada dos destinatários. Não se deve esquecer que a finalidade da obra, neste contexto, enquanto teatro sacro católico, concernia diretamente ao bem comum, encenação dos valores e princípios que mantinham evidentes os fundamentos teológicos e a dignidade da república absolutista. É também, portanto, uma parte das conveniências da própria república, do grande projeto político do estado que é justificado como continuação do projeto de Deus mesmo. A orientação tocava aos preceitos retórico-teológicos, que o artista ou artesão conhecia pela leitura dos tratados ou, principalmente, pelo percurso coletivo da própria tradição oficial corporativa de que fazia parte. Os lugares-comuns do gênero o artista também deveria escolher da tradição. A invenção das artes (inventio), ou seja, o primeiro dos procedimentos retórico-artísticos, consistia na prudente escolha dos lugares-comuns (topoi) adequados ao assunto do discurso artístico, ao gênero, ao contexto e circunstâncias, a serem ordenados também convenientemente pelo segundo procedimento retórico, ou seja, a disposição (dispositio). No âmbito das artes figurativas, como já dissemos, os lugares comuns eram recolhidos em várias fontes de longas e variadas durações: nos tratados e na tradição, nas representações da Bíblia, nas gravuras em circulação. No âmbito da arquitetura e da cidade, os lugares-comuns arquitetônicos se consagraram na longa tradição da fábrica artístico-construtiva lusobrasileira: uma série de elementos que caracterizaram essas cidades luso-brasileiras: os conjuntos uniformes de casas caiadas, os adros e largos defronte às igrejas e capelas via de regra implantadas em elevação, as casas de câmara e cadeia e os pelourinhos, signos temporais do poder e da justiça, as ruas "direitas" e travessas, as técnicas de construção adequadas, a importância de se considerar o sítio de implantação etc.

A direção capital do corpo político era responsabilidade do rei. Como "cabeça" deste corpo, ele tinha duas obrigações fundamentais: 1) garantir a paz e a unidade do estado, e, 2) dirigir todos e tudo rumo ao bem comum $^{\text {xlv }}$. Garantido isto, pelo menos em discurso, estariam assegurados a saúde do corpo do estado e o bem de cada "sócio", membro ou parte do corpo político e social. A hierarquia do estado procurava imitar a hierarquia própria das coisas celestes ou divinas, consagradas na Bíblia, no patriarcado bíblico e romano e pela teologia dos doutores da igreja. A igreja, ordenada 
espiritualmente pelo corpo místico de Cristo, deveria naturalmente ordenar o corpo político que conservava e orientava, através de uma verdadeira ética das virtudes, a sociedade dos homens. Lugar-comum entre os antigos, Platão, Aristóteles e Cícero: a ordem desenvolve e evidencia as virtudes, numa recíproca estratégia de promoção. A virtude orienta o homem ao conhecimento e busca pela ordem, o convívio com a ordem proporciona e desenvolve as virtudes nos homens. A sociedade católica fundamentou sua existência nas virtudes, dos homens e exemplarmente do rei, argumentando contra o artifício e o ardil sustentados pela Razão de Estado maquiavélica, e contra as malafamadas "heresias" de Calvino, Lutero e Melanchton. Sustentar a dignidade do reino significava sustentar inabalável a hierarquia - um sinal de ordem. O rei deveria granjear "amor" e "reputação" junto aos súditos. Para conseguir isto, oferecendo o melhor exemplo das virtudes estimuladas pela teologia cristã, ele deveria ser prudente, discreto, justo, forte, piedoso, magnânimo e liberal para com seus vassalos. Finalizava tudo na conservação do amor do bem comum, resultado bastante esperado num contexto em que o princípio ordenador de tudo não era senão o espírito amoroso e onipresente de Deus.

Representando esta ética católica hierárquica, encontramos alegorias das virtudes no lugar da mais alta hierarquia artística da capitania de Minas Gerais: a capela-mor da Igreja Matriz de Nossa Senhora do Pilar de Vila Rica. Estão todas as sete virtudes cardeais e teologais acomodadas sobre a cornija de coroamento da capela, trazidas, segundo reza a historiografia, da arquitetura efêmera que serviu às exéquias de Dom João V. Se foram ou não trasladadas da arquitetura efêmera que celebrou a morte do virtuoso rei (e a morte neste contexto tinha outra compreensão diferente da nossa, um misto de dor pela partida e de alegria pela iminente participação celeste), importa salientar que estão em muito adequado lugar - naquele o mais digno do mais importante dos sacrifícios católicos celebrados na capitania de Minas Gerais durante a primeira metade do século XVIII. E não é por acaso, pelo tudo que tenho dito, que as virtudes e o santíssimo sacramento da eucaristia se integraram na mesma e altíssima capela da Igreja Matriz. A invenção das virtudes e a disposição adequada dos valores sagrados evidenciam a prudência, o decoro e o engenho dos responsáveis.

A hierarquia orientava a ordem, ou disposição, dos elementos nos distintos corpos artísticos. Os vários elementos, estruturas e estilemas trabalhavam via de regra em função de uma cena ou de uma imagem principal, de um rito principal, de um 
argumento principal a ser ressaltado. Os altares-mores são dedicados ao orago principal ou ao próprio Jesus Cristo, ladeados pelos altares menores que trazem sempre os santos relacionados à devoção da irmandade; no caso da matriz, os oragos das próprias irmandades. No teatro da cidade, os lugares mais privilegiados são ocupados pelos edifícios oficiais e religiosos. Os templos deveriam obedecer a requisitos de dignidade e decência bastante coerentes com sua posição. A recomendação aparece em vários tratados vigentes no século XVIII, sobre a arte religiosa católica, e na constituições primeiras do arcebispado da Bahia, regulações expressamente comentadas nas visitas pastorais do século XVIII em Minas Gerais. Estamos bastante habituados a ver em nossas povoações do período colonial inúmeros edifícios religiosos, igrejas e capelas. Estes edifícios prevaleceram no processo de formação dessas povoações e evidenciam nelas um caráter religioso indiscutível, característico mesmo dessas povoações. Penso particularmente em Minas Gerais, cuja paisagem acidentada oportunamente permitiu dispô-los, como recomendavam tratados e regulações eclesiásticas, em ombreiras e cumes de morros, o quanto possível isentos das águas e de tudo que não fosse limpo, decente e asseado. Assegurar a decência das partes da cidade e principalmente dos edifícios religiosos servia à representação decente da própria república, da soberania do reino e de seus postulados teológico-políticos, representações construídas de uma dignidade hierárquica que prevalecia sobre o restante da povoação.

A noção de "ordem" orientava a "disposição" adequada das várias "partes" de qualquer corpo instituído pelo homem, político, artístico etc. No âmbito da arquitetura e do urbanismo, a disposição adequada e conveniente de edifícios e estruturas urbanas deveria reproduzir e representar, como princípio mas também como garantia de aparência conveniente, a ordem sagrada subjacente à política portuguesa postulada em nome de Deus. Não foram poucas as requisições de ordem, decência, dignidade, conveniência, grandeza, aparato, ornato, asseio, elegância, formosura etc., presentes em todas as etapas da fábrica artístico-construtiva colonial setecentista, desde a escolha dos sítios para implantação de novas povoações xlvi até a "necessária”, assim sempre declarada, ornamentação dos edifícios. A integridade do reino, e de sua política, dependia, física e aparentemente, da integridade de suas "partes", com especial atenção para os edifícios, arruamentos, largos e praças, "partes" constitutivas da cidade. A integridade física, bem como a aparência e a conservação dessas partes construídas estava orientada, na execução e no ornato, pela satisfação desses preceitos que 
formavam uma verdadeira rede de princípios competentes à dignidade e à decência da cidade - por extensão corporativa, de toda república.

Embora se classifique geralmente a arquitetura colonial luso-brasileira em três grandes gêneros, cito: "arquitetura religiosa", "arquitetura civil" e "arquitetura oficial", não apenas a última representava "oficialmente" o poder ou a presença reguladora da coroa na colônia. Em verdade, cada um desses gêneros de arquitetura possuía uma utilidade e um papel ordinário bem definido, mas sua presença como "parte" da povoação e do reino representava mais ao discurso retórico-teológico da colonização. Todas elas estavam perpassadas por princípios de ordem, unidade e decoro necessários à representação dos pressupostos político-teológicos. Os vereadores de Vila Rica, por exemplo, dedicaram "acordãos" e "vereações" da Câmara a vistorias públicas que exigissem de particulares várias disposições em prol do "bem comum" de "toda a república", como emenda e reedificação de casas, realinhamento de fachadas, substituição de materiais "inconvenientes" e "indecentes", "limpeza" e "asseio" das vias públicas etc. Os mesmos vereadores das Câmaras, em várias vilas da capitania, reclamavam constantemente à coroa que as casas de câmara e cadeia estavam em condições “indecentes”, pedindo auxílio ao rei para reconstrução, ampliação ou reforma. Alegavam sempre que não era digno ver os homens públicos, juízes e vereadores, realizando "atos públicos" tão importantes em um edifício "indecente" coberto de "palha", enquanto, por exemplo, a maioria das casas dos particulares já estava coberta de "telha". Difícil saber se todas essas disposições eram consequientes, importando por ora verificar sua presença reguladora e os efeitos que eram requeridos através delas. Notáveis são as requisições constantes de "conveniência" e "decência", termo este o mais apropriado para assegurar e resguardar o "decoro do sagrado"xlvii, para todas as partes envolvidas, edifícios e arruamentos, praças e ornatos.

Quero concluir dizendo que o interesse pela ordem colonial e seus pressupostos me parece imprescindível para o melhor entendimento da arte e da arquitetura produzidas na América portuguesa até pelo menos o início do século XIX. Compreender a ordem desses objetos artísticos é tentar compreender a lógica das invenções, das disposições e das ornamentações que constituíam parte de uma ordem maior, dentro da qual aquela estava integrada e servia como parte e meio necessário, apropriado e conveniente para um fim projetado ao bem comum da república católica colonial. 
Sensos comuns que pairam sobre esses objetos remanescentes do século XVIII querem nos fazer acreditar que eles nasceram "espontâneos" ou "desordenados", ou que tentaram heroicamente se desviar da "ordem" e da "regulação" metropolitanas tentativas modernas de se construir uma identidade nacional a partir de raízes de um país que não existia no século XVIII. São compreensões bastante delicadas de se aceitar quando se procura compreender o regime teológico-retórico dentro do qual estavam inseridos esses objetos no momento em que foram produzidos. Apesar de terem sido importantíssimas, essas compreensões precisam ser revistas. Atentar para os aspectos específicos da produção desta arte colonial, os princípios coevos como ordem, justiça, conveniência, decoro, formosura, etc. não quererá dizer que esses artistas e artífices, responsáveis anônimos ou não pela produção artística setecentista, tenham sido menores ou menos importantes do que pensávamos. A busca pela ordem dos objetos segundo a lógica devida de seus tempos (e não segundo a lógica dos tempos dos autores que sobre eles escreveram) promete restaurar-lhes uma história, pelo menos, mais verossímil.

\footnotetext{
' Apresentado no II Seminário Interpretar Arquitetura. Belo Horizonte, Novembro de 2005. (Disponível também em www.arq.ufmg.br/ia)

ii APM CMOP 06, fot. 1177-1178.

iii "Piíssima", "piedade", "pia", termos que aparecem aqui não com o sentido moderno de compaixão, e sim com a acepção antiga de sentimento religioso. Após o Concílio de Trento e concernente ao programa de fé da Igreja Católica em luta contra a reforma, o protestantismo e as heresias, foi exaltada a "piedade antiga", sentimento de fé exemplar nos primeiros séculos do Cristianismo. Esta "piedade" exemplar foi reclamada pelo Bispo de Milão, São Carlos Borromeu, em seu importante tratado sobre a arte e arquitetura religiosa, apresentado em 1577 - Instructiones fabricae et supellectilis ecclesiasticae. Durante a reforma católica, a arte e a arquitetura seriam especialmente responsáveis por recuperar a "piedade" dos fiéis, através do "esplendor", do "decoro" e da "magnificência" dos espaços de culto

iv APM CMOP 06, fot. 1177-1178.

${ }^{v}$ APM SC 18, f. 99.

vi "[...] a ordem era ignorada pelos portugueses como assinalavam deliciados os viajantes. As suas ruas, ironicamente chamadas 'direitas', eram tortas e cheias de altibaixos, as suas praças de ordinário irregulares". Cf. SMITH, Robert. Arquitetura Colonial (As artes na Bahia, I parte): Livraria Progresso, 1955. p. 12. Cf. também HOLANDA, Sérgio Buarque de. Raízes do Brasil. São Paulo: Cia das letras, 1997. Cap. 4: O semeador e o ladrilhador, p. 93-138.

vii João Adolfo Hansen costuma tratá-la também como uma "teologia política". O que importa é reconhecer a união entre a igreja católica e o estado, a ponto de poder ver coincididos seus interesses e estratégias. Cf. HANSEN, João Adolfo. Artes seiscentistas e teologia política. In: TIRAPELI, Percival (Org.) Arte sacra colonial: barroco memória viva. São Paulo: UNESP, 2001. p. 180-189.
} 
viii Por "lei natural" deve-se entender "as inclinações naturais das coisas", princípio que faz com que cada coisa tenda a realizar os fins para os quais são determinados. Cf. ROCAFULL, Jose M. Gallegos. La doctrina política del P. Francisco Suarez. México: Editorial Jus, 1948. p. 183.

${ }^{i x}$ Cf. HANSEN, op. cit, p. 185 et. seq.

${ }^{x}$ SARAIVA, F. R. dos Santos. Novissimo Diccionario Latino-Portuguez, etymologico, prosodico, historico... (10 edição - fac-símile da 9ª edição de 1927). Rio de Janeiro/ Paris: Garnier, 2000. “Ordo”, p. 826.

xi BLUTEAU, Raphael. Vocabulário Portuguêz, e Latino, Áulico, Anatomico, Architectonico... Coimbra: Real Collegio das Artes da Companhia de Jesu, 1712. "Ordem", v. 6, p. 102. (grifo do autor).

xii COLE, Thomas. The Origins of rehtoric in ancient Greece. Baltimore/ Londres: The John Hopkins University Press, 1995. p. 35.

xiii Idem, p. 145.

xiv PLATÃO. Diálogos. Trad. de Jorge Paleikat. Rio de Janeiro: Ediouro. Fedro. p. 168. (Clássicos de Bolso).

xv ARISTÓTELES, Arte poética. In: Aristóteles, Horácio, Longino. A poética clássica; trad. de Jaime Bruna, São Paulo: Ed. Cultrix, 1997. p. 27.

xvi "Suponhamos que um pintor entendesse de ligar a uma cabeça humana um pescoço de cavalo, ajuntar membros de toda procedência e cobri-los de penas variegadas, de sorte que a figura, de mulher formosa em cima, acabasse num hediondo peixe preto; entrados para ver o quadro, meus amigos, vocês conteriam o riso? [...] Creiam-me, Pisões, bem parecido com um quadro assim seria um livro onde se fantasiassem formas sem consistência, quais sonhos de enfermo, de maneira que o pé e a cabeça não se combinassem num ser uno". HORÁCIO. Arte poética; epistola ad Pisones. In: Aristóteles, Horácio, Longino. A poética clássica. 1-9, p. 55.

xvii No belo de estudo de Paula da Cunha Corrêa, encontram-se os vários usos do termo "harmonia" na antiga Grécia. Como termo técnico da carpintaria e da marcenaria, as "amarras" utilizadas para articular e vincular as distintas partes de uma estrutura; no sentido figurado de um "pacto", "laços travados entre duas ou mais partes"; como divindade ou personificação que assume vários nomes e formas, "Harmonia, Afrodite ou Philía", que "harmoniza o mundo por meio de um processo de unificação". Assim, "com suas harmoníai, os artesãos humanos criam artefatos ajustando as partes em um todo e, da mesma maneira, os artesãos divinos, demiurgos ou forças, criam ou mantém a ordem cósmica"; além do sentido musical, em que harmonia é obtida pela afinação das cordas da lira, a "série de notas empregadas em uma melodia particular". Cf. CORRÊA, Paula da Cunha. Harmonia: mito e música na Grécia antiga. São Paulo: Humanitas FFLCH/USP, 2003. (Coleção Letras Clássicas). p. 33-35.

xviii Cf. Lucas, 24: 49; Marcos 13: 11; João: 16: 5-15; Atos 2: 1-13.

xix A ressalva do pecado original (empregada por Lutero em suas teses para justificar a mancha irrevogável dos homens) não foi o bastante, segundo os doutores católicos, para negar a graça divina aos homens. Apesar do pecado, Deus continua a iluminar os homens em suas consciências, e também na produção da arte, através da luz da graça inata que orienta o artista. Cf. HANSEN, op. cit.

xx Não tem sido fácil aos estudiosos rastrear as fontes das alegorias bíblicas, embora seja possível apontar textos anteriores em que elas aparecem, constituindo tópicas autorizadas para a redação das sagradas escrituras. Autores se debruçaram sobre os aspectos retórico-poéticos da tradição cristã e do próprio texto bíblico, sobretudo do novo testamento, apontando-lhes os lugares-comuns, estratégias, argumentos, interpretações, preceitos e fundamentos. Cf. especialmente KINNEAVY, James L. Greek Rhetorical origins of Christian faith; an inquiry. New York/Oxford: Oxford University Press, 1987, e GINZBURG, Carlo. Relações de Força; história, retórica, prova. São Paulo: Companhia das Letras, 2002 e GINZBURG, Carlo. Olhos de Madeira; nove reflexões sobre a distância. São Paulo: Companhia das Letras. 2001. Ecce, sobre as raízes culturais da imagem de culto cristã. p. 104-138.

${ }^{x x i}$ Nos Atos dos apóstolos, evidencia-se mais uma vez o engenho de Paulo na tentativa de persuadir os gregos à conversão para o nascente Cristianismo. Na introdução de um dos seus discursos, em Atenas, Paulo enuncia que vai falar aos gregos de um deus que eles já haviam reconhecido de alguma forma. Paulo se refere então ao "Deus desconhecido", ao qual os gregos haviam erigido um templo na cidade. (Cf. Atos, 17: 23) Agradeço esta referência ao professor Jacyntho Lins Brandão, em uma de nossas conversas sobre a Retórica antiga. 
xxii I Coríntios 12: 12-30.

xxiii Cf. Hansen, Artes seiscentistas e teologia política. p. 185.

xxiv Cf. ROCAFULL. La doctrina política del P. Francisco Suarez. p. 34. Investigando a União e as possibilidades de "encarnação" do Verbo divino na Natureza, Santo Tomas de Aquino expõe a manifestação da "ordem" (commensuratio) através da arquitetura: "uma casa é feita de pedras e tijolos arranjados em ordem, conformados a uma figura". Cf. Tomas de Aquino. The Summa Theologica of Saint Thomas Aquinas. London: Encyclopaedia Britannica. Parte III, Q. 2, Art. i. p. 710, v. 2.

${ }^{x \times v}$ ROCAFULL. La doctrina política del P. Francisco Suarez. p. 34.

${ }^{x x v i}$ ROCAFULL. La doctrina política del P. Francisco Suarez, p. 52.

xxvii ROCAFULL. La doctrina política del P. Francisco Suarez, p. 189.

xxviii ROCAFULL. La doctrina política del P. Francisco Suarez, p. 106; p. 165.

${ }^{x x i x}$ ROCAFULL. La doctrina política del P. Francisco Suarez, 165-166.

${ }^{x x x}$ ROCAFULL. La doctrina política del P. Francisco Suarez, p. 167.

xxxi ROCAFULL. La doctrina política del P. Francisco Suarez, p. 167. Cf. também HANSEN, João Adolfo. Artes seiscentistas e teologia política. p. 180-189.

xxxii Denomina-se "razão de estado católica" o pensamento que influiu na formação e manutenção das repúblicas católicas contra-reformistas, em resposta às formulações políticas de Maquiavel, baseadas no artifício e na força do poder, consideradas tirânicas e contrárias à lei de Deus. Cf. HANSEN, João Adolfo. Razão de estado. In: A Crise da razão (org. Adauto Novaes). São Paulo: Cia das Letras. 1999.

xxxiii BOTERO, João. Da razão de estado. (Luís Reis Torgal, coord. e introd.; trad. de Raffaella Longbardi Ralha). Coimbra: Instituto Nacional de Investigação Científica/ Centro de História da Sociedade e da Cultura da Universidade de Coimbra, 1992. Livro I, p. 12-14.

xxxiv Ibidem.

${ }^{x x x v}$ BOTERO. Livro I, p. 19. (grifo nosso).

xxxvi ARISTÓTELES, Ética a Nicômano. São Paulo: Nova Cultural, 1996. Livro V, 3, p. 198-199.

xxxvii ROCAFULL. La doctrina política del P. Francisco Suarez, 171.

xxxviii ROCAFULL. La doctrina política del P. Francisco Suarez, p. 23-24; 171-174.

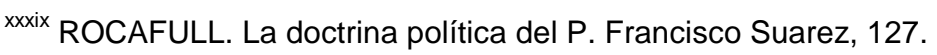

${ }^{x l}$ ROCAFULL. La doctrina política del P. Francisco Suarez, p. 34.

xli Cf. Hansen, op. cit., p. 181.

xlii Vale a pena conferir o estudo de JORDÃO, Paulo Vicente da Veiga. Corpo Santo; alegorias do corpo místico no barroco mineiro. Monografia (Especialização em cultura e arte barroca)-Instituto de Filosofia, Arte e Cultura/UFOP. Ouro Preto, 1996. (Orientada pelo Prof. Dr. João Adolfo Hansen).

xliii HANSEN, João Adolfo. Artes seiscentistas e teologia política, p. 188.

xliv Gregório de Matos e Guerra (como consta de atribuição) consagrou um soneto ao braço de uma imagem de Jesus menino que exemplifica muito bem esta compreensão da unidade conveniente do corpo e das partes. "Ao braço do mesmo menino Jesus quando appareceo: O todo sem a parte não é todo,/ A parte sem o todo não é parte,/ Mas se a parte o faz todo, sendo parte,/ Não se diga, que é parte, sendo todo./ Em todo o Sacramento está Deus todo,/ $\mathrm{E}$ todo assiste inteiro em qualquer parte,/ $\mathrm{E}$ feito em partes todo em toda a parte,/ Em qualquer parte sempre fica o todo./ O braço de Jesus não seja parte,/ Pois que feito Jesus em partes todo,/ Assiste cada parte em sua parte./ Não se sabendo parte deste todo,/ Um braço, que lhe acharam, sendo parte,/ Nos disse as partes todas deste todo". 
xlv Suarez considerava três modos legítimos de governo: a democracia, a aristocracia e a monarquia. Embora a democracia fosse idealmente a mais legítima delas, a sujeição de todos em nome de uma só cabeça mandante, o rei, facilitava a administração do bem comum. Cf. ROCAFULL, op. cit., p. 72.

xlvi Cf. BASTOS, Rodrigo Almeida. A Arte do Urbanismo Conveniente: o decoro na implantação de novas povoações em Minas Gerais na primeira metade do século XVIII. Dissertação (Mestrado em Arquitetura e Urbanismo)-Escola de Arquitetura, UFMG, Belo Horizonte, 2003.

xlvii Desenvolvi o preceito da "decência" na dissertação de mestrado, destacando suas excelência e aptidão tradicionais para tratar, guardar e requerer o "decoro do sagrado". Cf. BASTOS. A arte do Urbanismo Conveniente; 2.3 Decência e dignidade, p. 62-72. 